\title{
W stronę mowy pozornie niezależnej, czyli o dialogu w polskiej prozie współczesnej
}

ABSTRACT. Mizerkiewicz Tomasz, W strone mowy pozornie niezależnej, czyli o dialogu w polskiei prozie współczesnej [Towards reported direct speech (dialogue in the Polish contemporary prose)]. "Przestrzenie Teorii" 3/4, Poznań 2004, Adam Mickiewicz University Press, pp. 239-251. ISBN 83-232-1454-9. ISSN 1644-6763.

Dialogue as a part of Polish prose didn't attract enough attention. Its form changed along with literary conventions, for instance - realistic novels imitated common conversations. Nowadays Polish novelists use dialogues rather incidentally and often stress its unauthenticity. The speach of character is always quotation of phrases heard before. The new form of dialogue can be traced in Polish prose - some sentences seem to be given as direct speach, but close examination of their construction reveals their inderict essence. It should be called "reported direct speach" (as negative of "free indirect speach"). This form of dialogue is part of an important process descibed by contemporary philosophers as triumph of culture of writing over traditional culture of voice.

Kariera dialogu jako pewnej praktyki społecznej, postawy filozoficznej, perspektywy oglądu różnych znaczeń całości dzieł sztuki, w tym dzieł literackich $\mathrm{w}$ szczególności, nie idzie $\mathrm{w}$ parze $\mathrm{z}$ zainteresowaniem formą dialogu jako elementem kompozycyjnym utworów literackich. Filozofia dialogu, dialogiczność Bachtina, wszelkie odmiany sfetyszyzowanego dialogu jako pożądanej postawy politycznej powodują, że rozmowa ciekawi jako metafora postawy otwarcia na inność. Mamy przeto całkiem niezłe opisy hermeneutycznego znaczenia pytania, etycznego rozumienia odpowiedzi na wezwanie „inności innego”, niezliczone odmiany psychologii interakcyjnych i wszystkimi tymi zjawiskami humaniści ze zrozumiałych względów się fascynują. Jak to się wszak często w takich przypadkach zdarza, nadmierna popularność terminu przenosi rozważania nad dialogiem najczęściej na poziom metarefleksji metodologicznej lub filozoficznej. W efekcie liczba prac literaturoznawczych poświęconych dialogowi jako składowej literackiej kompozycji jest dość skromna. W Polsce prócz artykułu Głowińskiego ${ }^{1}$, książki zbiorowej z końca lat 70. Dialog $w$ literaturze ${ }^{2}$ oraz pracy Grażyny Borkowskiej o dialogach

1 M. Głowiński, Dialog $w$ powieści, w: tegoż, Narracje literackie i nieliterackie, Kraków 1997.

2 Dialog $w$ literaturze, red. E. Czaplejewicz i E. Kasperski, Warszawa 1978. 
w utworach Orzeszkowej ${ }^{3}$ uwag na interesujący mnie temat szukać trzeba w opracowaniach innych problemów, gdzie są one formułowane doraźnie, bez włączania ich $w$ jakiś ciąg ewolucji form dialogicznych w literaturze.

$\mathrm{Na}$ zajęciach z poetyki omawia się przeto przedwojenny artykuł Mukařovskiego 4 albo ogólny „katalog problemów” dotyczących morfologii dialogu, który sformułował Henryk Markiewicz w Wymiarach dzieła literackiego ${ }^{5}$. Te dwie prace nie dają wszak wglądu w problem zasadniczy dla poetyki - nie uświadamiają dość jasno, czym jest dialog jako konwencja literacka. Mukařovský opisuje strukturę dialogu jako naszego „życiowego" zachowania, co nie może zostać tak po prostu odniesione do fingowanych dialogów literackich, które wprawdzie czasem naśladują ową sytuację modelową, ale częściej poddają ją różnym odkształceniom. "Realistyczne" odwzorowania zachodzących w świecie empirycznym rozmów są, rzecz jasna, wynikiem wymogów realizowanej konwencji literackiej. Markiewicz powiada, że w kompozycji dzieła dialog odgrywa trzy funkcje: tworzy lub dynamizuje akcję, informuje o świecie przedstawionym, charakteryzuje przemawiające postaci. Dodać jednak koniecznie do tego trzeba, że sama forma dialogu nigdy nie jest przypadkowa, gdyż wpływa na nią zarówno konwencja literacka, do której odnosi się poetyka danego utworu, jak i zamysł kompozycyjny, któremu jest podporządkowana w tym jednym utworze. Inaczej mówiąc, dialog jest znaczącym problemem poetyki utworu, jego kształt nie wynika tylko z celów, które odgrywa w odniesieniu do elementów świata przedstawionego, jakimi są uwzględnione przez Markiewicza fabuła, postać i składniki „rzeczowe” owego świata. Kształt ten znaczy także jakby „na zewnątrz” tego świata, czyli możemy go odnosić do pozostałych chwytów kompozycyjnych analizowanego utworu, odczytywać na tle innych typów dialogów literackich, pytać o miejsce takiego ukształtowania formy dialogicznej w ciągu historycznej ewolucji tych form. W tekście poniższym zajmę się wyłącznie formą dialogów w utworach prozatorskich, ich związkiem ze wspomnianymi kontekstami poetyki. Rozważania te spróbuję umieścić na szkicowanym oczywiście wybiórczo i ogólnie, niemniej jednak bardzo istotnym tle historycznoliterackim.

${ }^{3} \mathrm{G}$. Borkow ska, Dialog powieściowy i jego konteksty (na podstawie twórczości Elizy Orzeszkowej), Wrocław 1988.

4 J. Mukařovský, Dialog a monolog, przel. J. Mayen, w: tegoż, Wśród znaków $i$ struktur. Wybór szkiców, Warszawa 1970.

${ }^{5} \mathrm{H}$. Markiewicz, Morfologia dialogu, w: tegoż, Wymiary dziela literackiego, Kraków 1996. 
Nie znamy dokładnie historii polskiego dialogu powieściowego ${ }^{6}$. Wacław Borowy w dwóch obszernych przypisach do książki o twórczości Ignacego Chodźki szkicowo przedstawił dzieje tego elementu kompozycyjnego utworów prozatorskich do połowy XIX stulecia 7 . W XVIII-wiecznej powieści pisarze wykorzystywali tyradę, czyli długą, silnie zretoryzowaną wypowiedź postaci („deklamacyjne dialogi w długopłynnych okresach pseudoklasycznego teatru" $-\mathrm{z}$ abominacją kwituje je Borowy) albo wprowadzali dialog rezonerski. Ten drugi typ mowy postaci bliski był monologowi, jako że zdecydowanie dominowała $w$ rozmowie jedna z postaci, reprezentowała ona poglądy autorskie, wykładała obszernie i wprost główne przesłanie ideowe dzieła. Przykładów tak skonstruowanego dialogu dostarczyć mógłby chociażby Pan Podstoli Ignacego Krasickiego. Na tym tle Borowy dostrzegł przełomowy charakter pisarstwa Juliana Ursyna Niemcewicza, Józefa Ignacego Kraszewskiego oraz Ignacego Chodźki ${ }^{9}$, którzy nadali dialogom powieściowym znamiona realistyczne.

Opis dialogu w powieści realistycznej zawdzięczamy artykułowi Michała Głowińskiego oraz świetnej pracy Grażyny Borkowskiej o dialogach w utworach Elizy Orzeszkowej. W powieści realistycznej XIX w. dialog stanowił jeden ze sposobów uprawdopodobnienia książkowego świata. Autor starał się stworzyć wrażenie, że na linii narrator-postać zachodzi równowaga, czyli że dialogi stanowią byt autonomiczny, nie podlegający narracyjnym obróbkom. Postaci wydać się przecież miały ,jak z życia wzięte", stąd czytelnik poznawal początek rozmowy, wysłuchiwał nieraz niezbyt istotnych szczegółów dyskusji, konfrontowany bywał $\mathrm{z}$ wypowiedziami postronnych osób nawet wtedy, gdy nie wnosiły one niczego nowego do poruszanych kwestii. Jeżeli odbiorcy poznawali tylko fragment dialogu, to bywało to specjalnie uzasadnione. Odwzoro-

${ }^{6}$ E. Czaplejewicz próbował za to zarysować historię „dialogiczności” (termin przejęty z teorii M. Bachtina) polskiej literatury od renesansu do współczesności. Propozycja ciekawa, ale raczej mało przydatna $z$ powodu nadmiernie obszernej definicji samej "dialogiczności”, która miałaby się objawiać w zjawiskach tak odmiennych jak koncept, poemat heroikomiczny, ironia, satyra itd. Nic dziwnego, że artykuł kończy się przesadzoną pointą: "Cała historia literatury jest w istocie historią dialogu" - E. Czaplejewicz, Dzieje dialogu w literaturze (próba postawienia problemu), w: Dialog $w$ literaturze, op. cit., s. 310.

7 W. Borowy, Ignacy Chodźko. (Artyzm i umyslowość), Krakbw 1914. Chodzi o przypis 34 (s. 101-103) i 60 (s. 114-117).

B Tamże, s. 114. Zob. także M. Siuciak, „Rozmowa albo dialog...” - wykorzystanie modelu ustnej komunikacji w literaturze XVI $i$ XVII wieku, w: Gatunki mowy $i$ ich ewolucja, t. II, Tekst a gatunek, Katowice 2004.

9 Zdaniem Borowego, pierwszy znaczący krok w stronę zróżnicowania mowy postaci uczynil J. U. Niemcewicz. W powiastce Dwaj panowie Sieciechowie pochodzący z początku XVIII i początku XIX wieku bohaterowie piszą odmienną polszczyzną, a w powieści Lejbe i Siora Niemcewicz naśladował polszczyznę Żydów. 
wywana spontaniczność, udawana chaotyczność rozmów przynosiły zatem szereg wypowiedzi i stwierdzeń niepotrzebnych $\mathrm{z}$ punktu widzenia powieściowej akcji. Nadmiar ten doprowadzić miał do Barthes'owskiego "efektu realności". Redundancja dialogowa, "wata słowna" przekonywać mialy, że bohaterowie "potrafią" trochę przynudzać, mówić nie na temat i popełniać krocie innych nie sprzyjających „konstruktywnej” rozmowie niestosowności, czyniąc dokładnie tak, jak to się zdarza samemu czytelnikowi w jego „nieksiążkowym” życiu. Dialog w owych utworach miał nade wszystko uobecniać prezentowany świat. W chwili rozwinięcia sekwencji dialogowej autor przenosił odbiorcę z czasu narracji do czasu fabuły. Ten przeskok czasowy rzadko w prozie realistycznej mial charakter szokowy, narrator raczej stopniowo przygotowywał czytelnika do wystąpienia bohaterów ${ }^{10}$. Poprzez opisy otoczenia, wyglądów postaci, zarysowanie sytuacji, w której usłyszymy ich słowa, oczywisty dystans między czasem fabuły i czasem narracji bywał zacierany.

Proza pierwszej połowy XX w. dokonała znaczącego zaburzenia opisanego powyżej stanu rzeczy. Zwrócono uwagę na fakt, że realistyczność powieści wcześniejszych była konwencjonalna i mistyfikowała faktyczne panowanie narratora nad światem przedstawionym. Opowiadający czuwał tam przecież, by dialogi nie przedłużały się w nieskończoność, „cenzurowal" wypowiedzi bohaterów, np. wymazując z nich wulgaryzmy; kiedy trzeba, streszczal część konwersacji11. Ta kosmetyka narratorska wynikała z tego, że książka stwarzać miała jedynie pozór realistyczności, poza tym podlegała wymogom atrakcyjności, ciśnieniom społecznych systemów etycznych itd. Dlatego ważne przemiany prozy już na przełomie XIX i XX w. doprowadziły do zakłócenia dotychczasowej równowagi na linii narrator-postać. Narrator bywał często detronizowany, jego punkt widzenia unieważniany, a pisarze wypracowywali różne metody zbliżania się do postaci literackich. Jedną z nich było rozszerzenie partii dialogowych, co doprowadziło potem do „powieści dialogowych”, takich jak np. utwory Parnickiego. Częściej spotykaliśmy się z sytuacją, gdy znikomym wtrąceniom narratora towarzyszyły liczne odsłonięcia świadomości bohatera, rzadziej zresztą przez dialog, a częściej przez strumień świadomości, marzenie senne itp. Slowa formułowane przez bohatera $\mathrm{w}$ rozmowie wydawały się dużo mniej interesujące od treści wylaniających się w monologach wewnętrznych. W takich przypadkach

${ }^{10}$ Czeski badacz dialogów, L. Doležel, rozróżniał dwa typy przejść od mowy narratora do mowy postaci: „zwrot ostry" $\mathrm{i}$ „Zwrot osłabiony" - O stylu moderní českê prózy: výstavba textu. Praha 1960. Podaję za: G. Borkowska, op. cit., s. 12.

11 Głowiński dodaje jeszcze: „kolokwialnośc i potoczność dialogu powieściowego jest następstwem nie reprodukowania żywej mowy, ale wypracowania takiej konwencji, która pozwalała tworzyć złudzenia naturalnosci, potoczności itp." - M. Głowiński, op. cit., s. 44. 
dialog bywał ograniczany jako jedna $\mathrm{z}$ form, nie najdoskonalsza, poznawania psychiki bohatera. Wreszcie możliwe było zachowanie odwrotne narrator ostentacyjnie ujawniał, że postaci są jego tworami i że może z nimi czynić, co się jemu żywnie podoba (ta sytuacja miała miejsce np. w powieściach-workach Witkacego). Jeśli podobnie "marionetkowa" postać została dopuszczona na chwilę do głosu, to głównie w tym celu, by narrator mógł zaraz skomentować wypowiedziane przez nią zdania. Analizując podobne przypadki w prozie Gombrowicza, Włodzimierz Bolecki stwierdzal w Poetyckim modelu prozy $w$ dwudziestoleciu międzywojennym, że narrator "czyha" tam na kwestie postaci ${ }^{12}$.

W konsekwencji tych przemian w prozie było albo za dużo, albo za mało dialogów w porównaniu z modelem wcześniejszym. Stało za tym dążenie do większej autentyczności prezentowanych postaci, ich usamodzielnienie od widocznych korektur wypowiedzi ze strony narratora miało przydać im psychologicznej wiarygodności i samodzielności. W „powieściach dialogicznych" człowiek istniał jako wynik zderzeń $\mathrm{z}$ cudzymi punktami widzenia, rodził się w konfrontacjach $\mathrm{z}$ odmiennymi doświadczeniami, był po Gombrowiczowsku „stwarzany" przez rozmowę. W drugim przypadku również chodziło o prawdę ludzkiej psychiki, lecz zakładano, że świadomość ma sferę „głębinową" blokowaną przez socjalizującą rozmowę, stąd ograniczano dialogi na rzecz mowy pozornie zależnej i monologów. Wariant ostatni upodrzędniał dialogi, ale z nieco innych powodów. Zaznaczano mianowicie, że prezentacja postaci, a zatem i ich rzekomych wypowiedzi, to elementy podległe decyzjom autorskim. Nigdy czytelnik nie obcuje z "autentycznymi postaciami” i ich prawdziwymi kwestiami. Podlegają one zmiennym konwencjom literackim i autorskim zamysłom. Dlatego ciekawsze od ich prezentowania jest analizowanie mechanizmów kreacji prozatorskiej. Miejsce dialogów zajmowal przeto monolog narratora-bohatera.

Oczywiście nie znaczy to, że nie korzystano w ogóle $\mathrm{z}$ takich form dialogicznych, które wypracowała powieść realistyczna. Pojawiały się one i pojawiają nadal, nawet dość często, jednak od opisanego momentu jasne się stało, że miejsce i rola dialogu w utworze prozatorskim zależy od podejmowanej przez pisarza konwencji literackiej. Powroty do realistycznego wyglądu dialogu musiały być jakoś dodatkowo umotywowane.

12 W. Bolecki, Poetycki model prozy $w$ dwudziestoleciu międzywojennym. Witkacy, Gombrowicz, Schulz i inni. Studium z poetyki historycznej. Kraków 1996, s. 141. Głowiński raczej pomijał ten trzeci typ dialogu we współczesnej powiesci, skoro widział ewolucję owego elementu kompozycyjnego następująco: „W prozie ostatniego stulecia obserwujemy jego [tj. dialogu - T. M.] nieustanną ekspansję, poszerzyły się jego kompetencje narracyjne, ograniczył on nie tylko panowanie, ale nawet samoistność języka narracji” - M. Głowińs ki, op. cit., s. 52 . 
Ponieważ brak opracowań opisujących dokładniej późniejszą ewolucję dialogów prozatorskich, spróbuję teraz dokonać wstępnego przeglądu kształtu i funkcji dialogów w prozie współczesnej. Wszystkie zaproponowane poniżej wnioski $\mathrm{z}$ konieczności będą miały charakter hipotetyczny. Skupię się tutaj głównie na tych typach dialogów z utworów prozatorskich, które swą kompozycją nawiązują do trzeciego $\mathrm{z}$ wyliczonych powyżej typów - dialogu ograniczonego przez narratora, a więc komentowanego, odczuwanego jako słowo sztuczne, cytowane, skonwencjonalizowane.

Rozpocząć chciałbym od omówienia książki Lecha Majewskiego Metafizyka ${ }^{13}$. Bohater-narrator wspomina w niej historię miłosną, której był uczestnikiem. Jego nadaktywność słowna powoduje, że dopuszcza partie dialogowe nader rzadko. Na pierwszy rzut oka zorientować się można, że dosłowne przytoczenia wypowiedzi własnych i ukochanej pojawiają się $\mathrm{w}$ prezentacjach chwil szczególnie ważnych. Pierwsze wymienione słowa, wyznanie miłości, wiadomość o śmiertelnej chorobie dziewczyny przytoczone zostały $\mathrm{w}$ mowie niezależnej. Zabieg ten przypomina nieco tzw. wierzchołkową akcję, tyle że przedstawianie kluczowych scen połączone jest $\mathrm{z}$ odtworzeniem równie kluczowych kwestii. Pisarz wykorzystał zatem „punktowo” potencjal przypisywany przez Markiewicza dialogom ich funkcję zdarzeniotwórczą, ale interesowały go tylko te dialogi, które wyznaczały perypetie, czyli nagłe zwroty w sytuacji kochanków. Zakładał, że czytelnik zechce „naocznie” świadkować przełomowej scenie, dlatego np. opis pierwszego spotkania zawiera krótki dialog o wielkości pływów morskich w Anglii, gdyż na ten temat wtedy przypadkowo bohaterowie rozmawiali. Dialog pełni tu funkcję retardacyjną, zatrzymuje czytelnika przy zdarzeniu ważnym dla książkowych protagonistów. Forma dialogiczna pojawia się w książce Majewskiego na tyle rzadko, że przytoczenie dosłowne ważkiej wypowiedzi często zaskakuje czytelnika. Zamiast spokojnego przygotowania do mowy bohatera czytelnik zostaje jakby na chwile „wrzucony w świat przedstawiony", a dokładniej - na moment przeniesiony $w$ czas fabuły. $Z$ tego względu zabieg niespodziewanego przytoczenia kwestii postaci świetnie nadaje się do zastosowania w puencie:

Opowiadałem ci to wszystko nerwowo, a ty położyłaś mi rękę na ustach, powstrzymując potok słów, i powiedziałaś po prostu:

- Jedźmy do Wenecji14.

Zacytowane zakończenie pierwszej części utworu zwraca uwagę z kilku powodów. Streszczeniu wypowiedzi bohatera-narratora towarzy-

13 L. Majewski, Metafizyka. Powieść, Kraków 2002.

14 Tamże, s. 42. 
szy oratio recta bohaterki. Wybrzmiewa ono w zakończeniu i wywołuje efekt zbliżenia do postaci, jaki wydać się może podobny do podobnych chwytów filmowych, kiedy to ujęta w zbliżeniu osoba wygłasza do kamery ważne słowa. Ten „zwrot do kamery” wynika m.in. z tego, że cała książka to opis scen zarejestrowanych przez bohatera na ręcznej kamerze. Jest jednak i inny powód - wygłoszona jakby „do kamery” riposta jest zarazem zdaniem kierowanym do odbiorcy, który w czasie następującej potem pauzy ma czas na to, by przemyśleć wagę usłyszanych słów, czyli zorientować się, że estetyzująca swe przeżycia dziewczyna pragnie przeżyć to samo, co bohater opowiadania Tomasza Manna Smierć $w W e-$ necji.

Dialog pojawia się w Metafizyce także wtedy, gdy jego treść dąży do anegdoty. W czasie wystawiania Odysei na brzegu londyńskiej Tamizy aktorzy posługiwali się mikrofonami, z tego powodu doszło do incydentu, który poznajemy $\mathrm{z}$ dialogu reżysera $\mathrm{z}$ głównymi bohaterami:

- Czytaliście w gazetach, jaką przygodę mieliśmy tu w zeszły piątek?

Ja czytałem, ale ty pokręciłaś przecząco glową.

- Nie? - zmartwił się i zdziwił. - Cały Londyn o tym mówi.

- O czym? - zapytałaś.

- Margaret Thatcher. Przemawiała na przyjęciu w ogrodzie Parlamentu. Byli wszyscy. I kiedy wznosiła toast, interferencja fal radiowych $\mathrm{z}$ mikrofonu Circe sprawiła, że Maggie opowiedziała, jak zamieniała ludzi w wieprze ${ }^{15}$.

W takich przypadkach dialog jest pozorny, wyzwala jedynie aktywność jednego z rozmówców, by zaprezentował anegdotę. Podobny typ wstawek minidialogicznych przypomina nieco różnego rodzaju żarty, gry słów (np. angielskie conundrumy), w których uobecniony, zwykle pytający lub potakujący bohater, sprowokować ma partnera do wypowiedzenia gotowego wicu, zaczepki czy wyzwiska.

Niemniej w Metafizyce spotykamy i kilka dłuższych dialogów. Zdarzają się one w scenach, w których bohaterowie rozmawiają o własnych New Age'owych fascynacjach. Na zmianę jeden $\mathrm{z}$ nich jest rezonerem, któremu rozmówca potrzebny jest do wygłoszenia przydługiego wykładu na dowolny temat. Czasem zdarzają się też obszerniejsze wymiany zdań, które przypominają niemal antyczne sympozjony - pozbawione ważnych odniesień do tła sytuacyjnego rozwlekłe rozmowy światopoglądowe. Obecność tego ostatniego typu rozmów również została szczególnie umotywowana. Otóż główny bohater stał się dzięki ukochanej na nowo ciekaw świata empirycznego. Książka Majewskiego to historia współczesnego człowieka, którego miłość wyrwała ze świata wirtualnego telewizji i internetu, by zmusić go do zadawania tzw. fundamentalnych pytań

15 Tamże, s. 27-28. 
o świat i czlowieka. Obszerne partie dialogów zaznaczyć mają pragnienie narratora-bohatera, by prowadzić autentyczne czy „istotne” rozmowy $\mathrm{i}$ kontaktować się niewirtualnie $\mathrm{z}$ drugim człowiekiem.

W książce Majewskiego można przeto znaleźć różne przejawy ostrożności czy podejrzliwości współczesnych prozaików wobec dialogu. Dialog grozi słowną watą, zbytkiem słów koniecznych, stąd wykorzystuje się go $\mathrm{w}$ ograniczonym zakresie. Zdaje się on świetnie spełniać rolę niespodziewanego przerywnika w narracyjnym słowotoku, wciąż budzi zaufanie jako chwyt uobecniający szczególnie ważne sytuacje, nadaje się do wprowadzenia dowcipu czy puenty. Detronizacja dialogu ma i tę zaletę, że wprowadzenie obszernych partii rozmów zmusza każdorazowo odbiorcę do zapytania o funkcję tak ,anachronicznego” zachowania autorskiego.

Przejdźmy do innych przykładów literackich. Kurczące się pole zastosowań dialogu i różne gry z konwencją dialogową polegają często na streszczaniu, omawianiu i wtapianiu wypowiedzi bohaterów w narrację. W opowiadaniu Wojciecha Kuczoka Cobyś widzioł... czytamy:

Miałem tedy judasza odkrytego na jasną godzinę, czas kąpieli gaździny; chodziłem więc wierciłem się zaglądałem do kuchni, gdzie w krzyżoka rżnięto i między meldunki dzwonkowe a winne się wtrącając pytałem: „Tata, a która to gaździna?", nawet przejęzyczenia nie zauważając z podniecenia, a chłopy śmiały się i meldowały: „Śtyrdzieści”, „Idźze, nie trza cię tu!”, „Łosimdziesiąt!”, „E, krucafuks, sto!"...16

Przytoczone wypowiedzi karciarzy ważne są z powodu swej natężonej wartości ilustracyjnej - narrator nie cytuje przecież dosłownie wszystkich wypowiedzi, zwracają one uwagę jako cytaty z języka karciarzy, a ich osobliwość wzmagają jeszcze elementy gwarowe. Narrator nie wyodrębnił także typograficznie tych wypowiedzi, lecz włączył je w swe wypowiedzenie, podkreślając ich streszczeniowy charakter. Podobne uksztaltowanie dialogu zapobiega znudzeniu czytelnika.

Streszczanie i omawianie rozmów postaci stanowi rodzaj wyzwania, przed którym staje każdorazowo piszący. Sposób streszczenia wypowiedzi bohaterów świadczy o artystycznym kunszcie, stanowi wręcz sprawdzian inwencyjnych uzdolnień piszącego. W opowiadaniu Kuczoka Pieron ognisty znajdujemy przykład minimonologu wypowiedzianego (bohater rozmawia przez telefon):

Nie, Gabryniu, wszystko w porządku, tylko mi w domu mózg czeszą pod wlos, mogę przyjść, tak, jak się umawialiśmy, jakie kolo, jak mechana, mój Boże, co za niezgrabna hiperbola, hi-per-bo-la, [...] w lóżku ci wytlumaczę, nic obraźliwego $[\ldots]^{17}$.

16 W. Kuczok, „Cobyś widziol...”, w: tegoż, Szkieleciarki, Krak6́w 2002, s. 59.

${ }_{17}$ Tegoż, Pieron ognisty, w: tegoż, Opowieści stychane, Kraków 2000, s. 18. 
Przykład powyższy przypomina ulubiony typ skeczu kabaretowego, w którym aktor finguje rozmowę telefoniczną, tworząc efekty komiczne poprzez nagłe przeskoki ku nowym znaczeniom (wynikające $\mathrm{z}$ „pominiętych" kwestii telefonicznego rozmówcy).

Nieco odmienny typ streszczeń dialogicznych polega na igraniu $\mathrm{z}$ banalnością skracanych wypowiedzi.

Jarek zapytał, czy zjem obiad, ja oczywiście, więc zeszliśmy na stołówkę $[\ldots]^{18}$

Wszystko, tylko nie to; więc powiedziałem: dobrze, dostałem klucze do jej mieszkania - zostałem opiekunem małego krokodyla ${ }^{19}$.

Monika zdziwiona, czemu na jednej nodze mam skarpetkę, więc jej opowiedzialem o elektrokoagulacji, a potem (skracam, skracam) powiedzmy, że już przyszedł Jarek, omiótł sytuację wzrokiem posępnym zza okularów, a ja do niego od razu z tymi słowami: Bo widzisz, Jarku, Monika ma do ciebie taką sprawę, myślę, że powinieneś się zgodzić ${ }^{20}$.

W następnych przykładach zauważyć można ten sam chwyt, który występował w utworach Gombrowicza. Narrator "czyha” tu na słowa postaci, krótko je przytacza, po czym zagaduje ich banalność lub odkrywa ukryte znaczenia w pozornie zwyczajnej wypowiedzi. Niejednokrotnie ubarwia „drętwą" mowę bohaterów komicznym dopowiedzeniem nadpisującym niespodziewane sensy nad trywialnością cytowanych odezwań.

[...] więc stoimy w tych drzwiach, spieramy się, aż wreszcie chłopczyk przywalił z grubej rury:

- Za mlody jesteś - mówi - żeby ze mną dyskutować.

- No coś ty - wyrwało mi się (głupio), ale jednocześnie poczułem, że jako „obrażony” (w rozkosznie podstawówkowym sensie) mam już teraz prawo zamknąć mu te drzwi przed nosem i przestać się nim interesować; kiedy wrócilem na tapczan, Monika powiedziała do mnie:

- Ty smarkaczu - czym objęła niespodziewanie wiele pól znaczeniowych ${ }^{21}$.

A $w$ ogóle to jak dzień? , zapytałem w końcu drewnianym głosem, z którego miało wynikać, że ogólnie kocham moją żonę, ale nie spodziewam się po jej odpowiedzi szczególnych rewelacji..22

Basia studiowała zoologię, co oczywiście fatalnie utrudniało sytuację: $\mathrm{z}$ moich słownych czułości musiały zniknąć najdrobniejsze wzmianki o faunie, już nie tylko banalne piesku i kotku, ale nieco bardziej wymyślne: foczko, lwiczko, zajq-

18 A. Wiedemann, Gwaltowne pogorszenie stuchu, w: tegoż, Sęk pies brew, Warszawa 1998 , s. 37 .

19 J. Sosnowski, Wszystko dla Basi, w: tegoż, Linia nocna. Singles Collection, Warszawa 2002, s. 21.

${ }^{20}$ A. Wiedemann, op. cit., s. 35.

21 Tamże, s. 46.

22 J. Sosnow ski, Mała futrzasta śmierć, w: Linia nocna..., s. 81. 
$c u$, budziło to wszystko protesty: studiuje życie zwierzqt, nie jestem jednym $z$ nich. Kiedy próbowałem tłumaczyć, że przyroda od dawna dostarczała motywów do miłosnych zaklęć, usłyszałem: możesz mówić do mnie Sępie ${ }^{23}$.

Znaleźć możemy we współczesnej prozie także nawiązania do „powieści dialogicznej":

Tad. Siedzi, oddycha, patrzy na Kryst., która siedzi, oddycha, pije kawę.

- Czy nie przesadzasz z tą zazdrością? - Tad. Pyta.

- Tak uważasz? - Kryst mówi, robiąc łyk.

- Myślisz, że móglbym cię zdradzić? - Tad. Pyta.

- A nie mógłbyś? - Kryst mówi, robiąc łyk.

- Ale po co miałbym cię zdradzać? - Tad. Pyta.

- A po co w ogóle się zdradza? - mówi Kryst, dopijają ${ }^{24}$.

Wszystkie zdania wypowiadane tu przez bohaterów rażą i zarazem śmieszą swą trywialnością. Narrator celowo potęguje ich bezznaczeniowość. Opowiadanie Trzydzieści trzy pytania stanowi bowiem realizację bardzo sztucznego założenia - napisać tak utwór, by wszystkie kwestie postaci były pytaniami. Można chyba powiedzieć o konceptystycznym wręcz wyzwaniu postawionym sobie przez piszącego. Zarazem narrator przemyca między komicznie banalnymi słowami protagonistów kolejne zdarzenia, które czytelnik musi rekonstruować na podstawie drobnych tylko sygnałów - układają się one w opowieść o zdradzie miłosnej.

Cały wachlarz pomysłów na uniezwyklenie konwencjonalnych, łatwych do przewidzenia słów postaci znaleźć można w twórczości Zbigniewa Kruszyńskiego. Pisarz ten sięga po formę dialogu dość rzadko i za każdym razem usilnie dąży do zaskoczenia czytelnika sposobem, w jaki zapisał przytaczany dialog. W Schwedenkräuter znajdujemy na przykład streszczenie dialogu, którego opowiadający... nie mógł usłyszeć! Bohater podgląda przez lornetkę lokatorów sąsiedniego budynku i tak odtwarza, na podstawie „mowy ciała”, możliwe kwestie kłócącej się młodej pary:

Młode małżeństwo na ostatnim piętrze odgrywa swą codzienną pantomimę kłótni. Ona ma tego dosyć, tak, żeby wiedział, dosyć, uderza otwartą dłonią w dzielący ich stół, aż lekko podskakuje przezroczysta szklanka. I proszę bardzo, proszę, droga wolna, proszę - pokazują oboje na drzwi do przedpokoju, jakby to było wyjście $z$ sytuacji. Tak dłużej już nie można - on rozkłada ręce i obejmuje wzorzec metra - przebrał miarę!

- Gdzie, gdzie rozum - próbuje go namacać, stukając wskazującym palcem w czoło ${ }^{25}$.

23 J. Sosnowski, Wszystho dla Basi, s. 20.

${ }^{24}$ W. Kuczok, Trzydzieści trzy pytania, w: tegoż, Opowieści slychane, s. 54.

25 Z. Kruszyński, Schwedenkräuter, Kraków 1995, s. 56-57. 
Znajdujemy również u Kruszyńskiego omówienie rozmowy. W tej formie można łatwo poddać wypowiedzi bohaterów obróbce żartobliwej czy kalamburowej. W czasie śnieżnej i mroźnej zimy zdarzyła się rzecz następująca:

Przy kolacji jedna z naszych wciąż obozujących w obozie rodzin obliczyła, że brakuje dwóch dziewczynek.

Policjanci nie wierzyli, sugerowali, by poczekać na roztopy, rozebrali nawet kilka bałwanów, ale w końcu dali się przekonać...26

Jeszcze ciekawsza jest technika dialogu cytowanego wyrywkowo. Czytelnik zmuszony jest wtedy rekonstruować przeoczone partie wypowiedzi bohaterów, jak np. w rozmowie ze studentką:

- Jak egzaminy, czy dużo jej zostało?

- Jeden egzamin, jedno zaliczenie, wykład, z którym może być kłopot, bo wcale nie chodziła.

- Wakacje?

- Nie wie, wszystko zależy od pieniędzy.

- Ciastka.

- Tak, sama, nic trudnego, biszkopt, czyli powietrze, które się zapiekło ${ }^{27}$.

Cytowalność jest tu zaznaczona poprzez paradoksalny chwyt, który należałoby nazwać mową pozornie niezależną. Wydaje się, że cytowane są dosłownie wypowiedzi postaci, gdyż kolejne kwestie wydzielane są poprzez myślniki i przeniesione zostają do nowej linii. Jednak zdania pojawiające się w owym formalnie „niezależnym” kontekście mają oczywiste znamiona mowy zależnej (gramatyczna trzecia osoba czasowników, latwo uchwytne zabiegi streszczania wypowiedzi). Przykładów na mowę pozornie niezależną dostarczają również utwory innych pisarzy. W Wojnie polsko-ruskiej Doroty Masłowskiej czytamy:

Ja wtedy trochę dostaję nerwów.

Ona zgłupiała do reszty? - krzyczę, bo to już mnie doprowadza do ostateczności, do zupełnej utraty równowagi umysłowej. Zgłupiała całkiem do reszty? Czy ona chce mi koniecznie problemy robić? Suki na chatę sprowadzać? [...] ona sobie raz wreszcie powinna pomyśleć poważnie i uzmysłowić, jaka jest umowa $[\ldots]^{28}$.

U Kruszyńskiego zaskakujący chwyt mowy pozornie niezależnej współistnieje często $\mathrm{z}$ okazyjnymi, jednorazowymi pomysłami na przytoczenie dialogu:

26 Tamże, s. 145.

${ }^{27}$ Z. Kruszy ński, Szkice historyczne. Powieść, [brak miejsca wydania] 1996, s. 62.

28 D. Masłowska, Wojna polsko-ruska pod flagq̨ biało-czerwonq, Warszawa 2002, s. 80. 
Zaglądała sąsiadka.

- Nie przeszkadza?

- Wcale.

Siadała wśród kanapek i konspiratorów.

- Swietna herbata - zdradzała niechcący przygotowane na inny dzień hasło.

- Dwie łyżeczki na kubek, my pijemy mocną - Ewa na poczekaniu wymyślała odzew ${ }^{29}$.

Widziałam cię w niedzielę, szedłeś z nimi [...] i ledwie zdążyłam schronić się w cukierni. Nie było kolejki, musiałam coś kupić:

- Sernik - powiedzialam.

- Zapakować?

- Tak, nie będę go przecież nie jadła na miejscu ${ }^{30}$.

W ostatnim z przypadków domyślamy się, że słowa, które zostały przytoczone, w rzeczywistości powieściowej wcale nie zostały wypowiedziane. „Nie będę go przecież nie jadta na miejscu” to słowny paradoks oddający pogmatwanie wewnętrzne zakochanej bohaterki, stanowi ekspresję przeżyć opisywanych w jej narracji, które wdzierają się do przytaczanych przez nią rozmów i wypaczają w streszczeniu ich realny przebieg.

Jeśliby pokusić się o podsumowanie powyższych uwag, to nasuwa się kilka ogólnych obserwacji. Przede wszystkim dialogi we współczesnych utworach prozatorskich są mocno ograniczane. Można w tym dostrzec pewien zabieg mimetyczny - naśladuje się w ten sposób i wyraża przekonanie o dokonującym się zaniku zdolności do towarzyskiej konwersacji, kultury rozmów i pogawędek. Po drugie, większość cytowanych autorów przejawia tendencję do uniezwyklania formy dialogu, jej konceptystycznego przerabiania, udziwniania. Krańcowym punktem dojścia owych zabiegów jest chwyt mowy pozornie niezależnej. Oddaje on w pełni przekonanie o sztuczności, „nierealistyczności” powieściowych dialogów.

Gdyby odwołać się do szerszego kontekstu filozoficznego, wówczas moglibyśmy powiedzieć, że omawiani pisarze wyjątkowo dobitnie potwierdzają zwrot ku pismu, jaki zainicjował Jacques Derrida. Poczucie, że słowa padające $\mathrm{w}$ dialogu są zapośredniczone, że dialog powieściowy to miejsce o szczególnie natężonej cytowalności, intertekstualności, podważają dziewiętnastowieczne przekonanie o zdolności przytoczonych w dialogu słów do uobecnienia głosu i mówiącego. W tym miejscu tekstu retoryka obecności szczególnie boleśnie traci swe uprawnienia. Pisarze współcześni odczuwają słowa swych postaci jako czyjeś, ujawniają ich

${ }^{29}$ Z. Kruszyński, Szkice..., s. 15.

30 Tamże, s. 196. 
sztuczność. Swiadomość poprzednich użyć języka literackiego powoduje, że byliby nieuczciwi, nie zdradzając wtórności słów wypowiadanych przez ich książkowe postaci. Formy dialogu w analizowanej powyżej części współczesnej prozy polskiej świadczą przeto o ważnym zjawisku kulturowym - o stopniowej detronizacji głosu na rzecz pisma ${ }^{31}$.

31 Por. artykuł B. Witosz, Literackie zapisy rozmowy $w$ tzw. mlodej prozie lat dziewięćdziesiqtych, w: Porozmawiajmy o rozmowie, red. M. Kita, Katowice 2003. 